\title{
Development of Maintenance Culture Model in Malaysian Local Authorities
}

\section{Suwaibatul Islamiah Abdullah Sani' ${ }^{1}$, Nurhayati Khair ${ }^{2}$, Junainah Mohamad ${ }^{1}$}

\author{
${ }^{1}$ Faculty of Architecture, Planning \& Surveying, \\ Universiti Teknologi MARA Perak Branch, Seri Iskandar Campus, Perak, Malaysia \\ ${ }^{2}$ Building and Property Management, Faculty of Accountancy and Management, \\ Universit Tunku Abdul Rahman, Sungai Long, Malaysia \\ sislamiah26@gmail.com,mjunainah@uitm.edu.my
}

\begin{abstract}
Infrastructure development is fundamental to the success of a country to achieve the status of the developed nation. However, the development made is deemed to be unsuccessful without a high culture of maintenance to maintain the existing infrastructure. Nevertheless, the effort is unworthy since the performance level for the maintenance of an immovable asset in Malaysia, especially those that belong to Local Authorities are still at an inadequate level. Local Authorities hold a large number of facilities that place demands on resources. The purpose of this research was carried to produce a structural model for developing of maintenance culture in Malaysian local authorities.
\end{abstract}

Keywords: maintenance culture; measurement model; structural model

eISSN 2398-4295 @ 2019. The Authors. Published for AMER ABRA cE-Bs by e-International Publishing House, Ltd., UK. This is an open-access article under the CC BY-NC-ND license (http://creativecommons.org/licenses/bync-nd/4.0/). Peer-review under responsibility of AMER (Association of Malaysian Environment-Behaviour Researchers), ABRA (Association of Behavioural Researchers on Asians) and CE-Bs (Centre for EnvironmentBehaviour Studies), Faculty of Architecture, Planning \& Surveying, Universiti Teknologi MARA, Malaysia. http://dx.doi.org/10.21834/ajbes.v4i15.170 


\subsection{Introduction}

Infrastructure development is fundamental for any successful nations to achieve developed nation status in the world and improving the quality of life. The governments' spend more expenditures and investments focus on infrastructural development even though the challenges in developed countries are sustainability (Odediran et al., 2012). However, without an adequate and high maintenance culture, efforts at infrastructure asset (including buildings) development will amount to nothing (Olufunke, 2011). According to Sani et al. (2014), Malaysia facing the challenges in sustaining and maintaining inadequate infrastructure especially for the local authority. The local authority facing with the challenges of supporting and maintaining infrastructure caused operation of public utilities are an inefficient and low quality of service delivery. The quality of service delivery could be assessed where customer satisfaction requirements have been fulfilled as it indicates the level of organizational performance (Kamaruddin et al., 2017).

The local authority have a responsibility to use and maintain a broad range of property assets including classified and heritage buildings, single purpose facilities and state of the multipurpose art facilities and also in urban area. Over the years, the local authorities in Malaysia currently have been soundly criticised by public caused poor maintenance culture. The assets primarily public buildings and infrastructures are not well maintained. This problem arises due to the poor maintenance culture that resulted in the fixed assets were not properly maintained. Thus maintenance culture has been recognised as an important aspect of increasing the quality of maintenance work to extend the life capacity of the assets and facilities. According to Florence (2011), maintenance culture is not universal, it is usually derived or learned from a person making maintenance a natural daily practice that can be followed and emulated by others. It's mean, maintenance culture began with the creation attitude, a change in mind set and the work process in an organization (Misnan and Samlawi, 2012).

Suwaibatul Islamiah et al. (2012) defined maintenance culture as the values, the way of thinking, behaviour, perception, and the underlying assumptions of any person or group or society that considers maintenance is a matter that is important (priority) and practices it in their life. When an individual or group has maintenance culture, they would have the attitude to maintain, preserve and protect public facilities. The aim of this paper was to study the key determinant factors that influence development of maintenance culture. Thus, the primary objective of this study is intended to create structural model of key determinant factors influencing the maintenance culture in Malaysian local authorities. The structural model was established by using Structural Equation Models Partial Least Squares (SEM-PLS) technique.

\subsection{Literature Review}

Current literature indicates that many studies on quality culture field and safety culture have discussed factors that influence the development of culture. Besides that, some studies have also examined about factors of culture development by researchers in maintenance culture field and school culture field. The study's factors that influence the development of culture 
gathered from previous studies as shown in Table 1.

Table 1. Previous Research

\begin{tabular}{ll}
\hline Factors & Source \\
\hline Leadership & Misnan and Samlawi (2012); Tungkunanan et al. (2008); Andi et al. (2005); \\
& MohammadZadeh and Saghaei (2009); Khoiri (2010); Christina et al. (2012); Zou \\
& (2010); Mohd Saidin (2009) \\
Teamwork & Misnan and Samlawi (2012); Tungkunanan et al. (2008); MohammadZadeh and \\
& Saghaei (2009); Zou (2010); Mohd Saidin (2009). \\
Training and & Misnan and Samlawi (2012);Tungkunanan et al. (2008); MohammadZadeh and \\
Education & Saghaei (2009); Andi et al. (2002); Khoiri (2010); Christina et al. (2012); Zou (2010); \\
& Mohd Saidin (2009). \\
Maintenance Policy & Misnan and Samlawi (2012); MohammadZadeh and Saghaei (2009); Andi et al. (2005); \\
& Khoiri (2010); Christina et al. (2012); Mohd Saidin (2009). \\
Communication & Misnan and Samlawi (2012); MohammadZadeh and Saghaei (2009); Andi et al. (2005); \\
& Khoiri (2010); Christina et al. (2012); Zou (2010); \\
& Mohd Saidin (2009). \\
Involvement & Tungkunanan et al. (2008); MohammadZadeh and Saghaei (2009); \\
& Andi et al. (2005); Khoiri (2010); Christina et al. (2012); Zou (2010); Mohd Saidin \\
& (2009). \\
\hline
\end{tabular}

From a review of these previous studies revealed six determinant factors can execute in developing of maintenance culture (Sani et al., 2012). Based on previous empirical research shown six factors identified as the key determinant factors of development maintenance culture. The factors could be specified as follows:

i. Leadership: Leadership behaviour styles are considered to be inspire to their followers and give influence to their personal characteristic and behaviour (Saad et al., 2017) such that they make an effort eagerly including goals, visions, and policy implementation towards achieving group goals (Zabihi et al., 2012).

ii. Communication: Communication is the process in which information is encoded and imparted by a sender to a receiver via a channel. The receiver decodes the message and gives the sender feedback (Perumal and Abu Bakar, (2011).

iii. Teamwork: Working in teams expedites the completion of tasks than those who work quietly as individuals, where more ideas would cultivate, and synergy could create amongst the members in groups (Syed-Abdullah et al., 2011).

iv. Training and Education: Training is the development of attitudes, knowledge and specialised skills required by the employees to perform their duties correctly. Education was for the promotion of learning and as an added value to the universal knowledge of the development of individuals and organisations (Sani et al., 2014).

v. Involvement: Employee participation in the organisation is a process that demands the workers participating in actions and the organisation (Sani et al., 2014).

vi. Maintenance Policy: The policies and strategies that comprised the mission statement, slogan or rules must be followed by an individual in an organisation to achieve goals (Sani et al., 2014). 


\subsection{Conceptual model for Key determinant factors of maintenance culture}

Figure 1 illustrates the conceptual research framework for six determinant factors of maintenance culture. The conceptual framework is created on the basic of finding from previous research. As illustrated in Figure 1, six hypotheses were describing the direct relationships among all factors with maintenance culture.

H1: Leadership has a significant and direct effect on Maintenance Culture

H2: Teamwork has a significant and direct effect on Maintenance Culture.

H3: Communication has a significant and direct effect on Maintenance Culture.

H4: Involvement has a significant and direct effect on Maintenance Culture

H5: Training and Education has a significant and direct effect on Maintenance Culture.

H6: Maintenance Policy has a significant and direct effect on Maintenance Culture

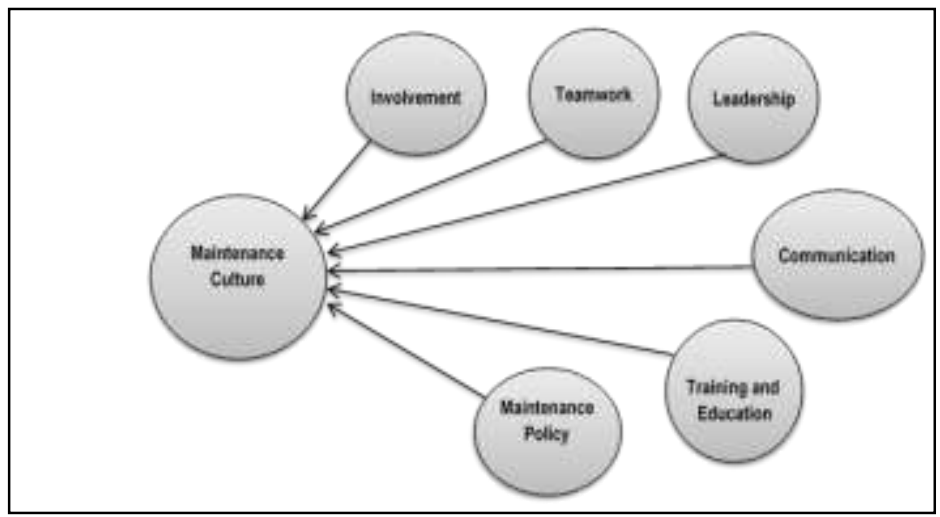

Fig. 1: Conceptual Model

The conceptual model comprises seven latent variables. 'Leadership', 'Communication', 'Teamwork', 'Training and Education', 'Involvement' and 'Maintenance Policy' are an exogenous variable and 'Maintenance Culture' is an endogenous variables.

\subsection{Methodology}

This research is using of Maintenance Culture Questionnaires (MCQ) as quantitative method tools for data collection. A stratified random sampling technique was selected to estimate the numbers of local authorities in Malaysia to be in the sample. This method adopted due to the diversity of types of local authorities in Malaysia. Figure 2 shows the sampling frame of the sample selection process that involves types of local authorities, zoning and the PBT Star Rating System. Therefore, a total 570 respondents from 19 local authorities involved in the questionnaires survey. 


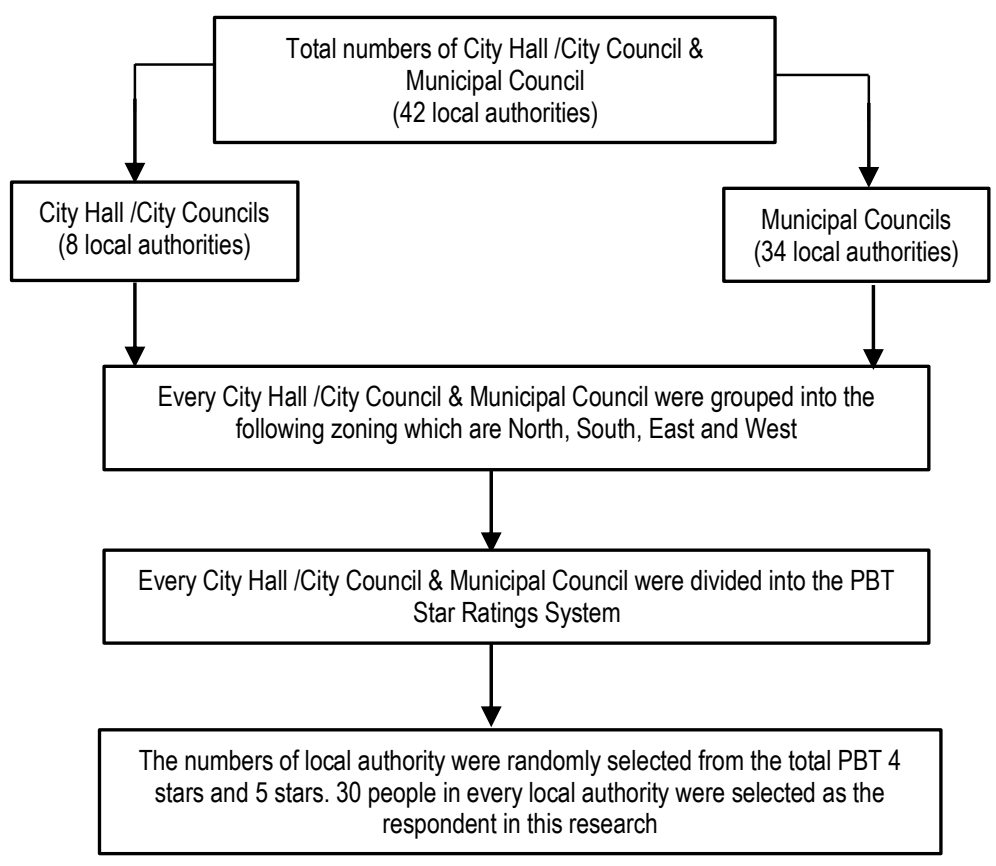

Fig. 2: Sampling Frame

The questionnaire surveys distributed among the management level and the technical staffs who executed of maintenance works. A total of 277 questionnaires were returned, corresponding to a response rate are lower with $49 \%$ because the method of data collection has used postal surveys. Thus, it is possibility contribute of a low return rate. The research instruments applied of this research is surveys to collect data among local authorities respondent. Three main sections are containing in this questionnaire, namely section $\mathrm{A}$ consisted questions for six key determinant factors of development maintenance culture, followed by part $B$ for measuring maintenance culture and finally section $C$ is to gather information concerning respondents' demographic profile. All questions in section $A$ and $B$ were measured using the 6-point Likert scale ranging from (1) Strongly Disagree to (6) Strongly Agree. A neutral scale was excluded in the questionnaire to avoid respondents answering all questions more too neutral point rather than other scales (Reiman and Oedewald, 2004).

The statistical technique of the structural equation modelling (SEM) was utilised as a method for analysing data. This method was empirically tested and validated the hypotheses developed (Hair et al., 2010; Urbach dan Ahlenmann, 2010) and also the simultaneous assessment of the structural component and measurement component in the complete one model (Mohd Suki et al., 2011). The purpose was to develop the structural model that 
explained the relationships among the latent variables which are coefficients of the inner mode (measurement model) and coefficients of the outer model (structural model).

\subsection{Results and Discussion}

\subsection{Demographic Respondents}

Table 2 presents descriptive statistics for respondents' working experience. Based on data analysis, there are five categories of working experience in the maintenance field. The most represented years of working experience were individuals between 6 and 10 years (35\%). Next, followed by the years between 1 and 5 years $(25 \%)$, then the 20 years above $(16 \%)$, followed by years between 11 and 15 years (13\%) and lastly is years 16 to 20 years (11\%).

\begin{tabular}{ll}
\multicolumn{2}{c}{ Table 2: Respondents' Working Experience } \\
\hline Years & $\%$ \\
\hline $1-5$ & 35 \\
$6-10$ & 25 \\
$11-15$ & 13 \\
$16-20$ & 11 \\
20 above & 16 \\
\hline
\end{tabular}

\subsection{Measurement model}

The analysis model explains the relationship between latent variables and the indicators (observed variables) for each latent variable (Henseler et al., 2009). The model assessments of the measurement model for identification the reliabilities and validities criteria of the variables (Hair et al., 2010). The first criterion examined was reliability, which refers to determine factors loadings and composite reliability. Lastly, developed model was confirmed by two subtypes of validities criteria include convergent and discriminant validities.

Table 3 shows the results of factors loading, composite reliability and convergent reliability $(\mathrm{AVE})$, from these results interpret that the factors loading for all indicators are range from 0.784 to 0.925 .

The results demonstrate that all variables in this model had achieved adequate indicator reliability due to the value which exceeds of 0.7 as suggested by Henseler et al. (2009). All constructs in the model had reached the requirements for composite reliability with every construct obtained values range from 0.901 to 0.945 . According to Bernstein and Nunnally (1994), the least acceptable for the value of composite reliability should be greater than 0.70 or 0.6 above. However, to be satisfied convergent validity requirement, the average variance extracted (AVE) of each construct should be higher than 0.50 which had been recommended by Fornell and Larcker (1981). The AVE value in the model shows 0.5 above, which is all constructs (latent variables) between 0.691 to 0.810 . The measurement model possessed adequate convergent validity. 
Abdullah Sani, S.I., et.al. / Asian Journal of Behavioural Studies (AjBeS), 4(15) Jan / Apr 2019 (p.39-50)

Table 3: Measurement Model Results

\begin{tabular}{|c|c|c|c|c|}
\hline Coretruds & "ients & Fadors Loxding & $\begin{array}{l}\text { Conpoente } \\
\text { Reliseility }\end{array}$ & AVE \\
\hline \multirow[t]{4}{*}{ Leaderstip } & KPIMN1 & 0.785 & 0.901 & 0684 \\
\hline & KP1MN2 & 0.871 & & \\
\hline & KPIMN3 & 0.654 & & \\
\hline & ICPIMN4 & 0.021 & & \\
\hline \multirow[t]{4}{*}{ Teormwork } & KPASU1 & 0.819 & 0.905 & 0.704 \\
\hline & KPASU2 & 0.832 & & \\
\hline & KPASU3 & 0.857 & & \\
\hline & KPASU4 & 0.848 & & \\
\hline \multirow[t]{4}{*}{ Communication } & KOMUN1 & 0.89 & 0.902 & 0.747 \\
\hline & KOMUN2 & 0.628 & & \\
\hline & KOMUN3 & 0.656 & & \\
\hline & KOMUN4 & 0.602 & & \\
\hline \multirow[t]{4}{*}{ Imolvertert } & UBAT1 & 0.082 & 0.906 & 0.706 \\
\hline & UBAT2 & 0.827 & & \\
\hline & บEAT3 & 0.819 & & \\
\hline & บBAT4 & 0.853 & & \\
\hline \multirow[t]{6}{*}{ Traing and Educstion } & LTPD1 & 0.903 & 0.945 & 0.743 \\
\hline & LTPDQ & 0.819 & & \\
\hline & LTPDB & 0.856 & & \\
\hline & LTPD4 & 0.004 & & \\
\hline & LTPDS & 0.856 & & \\
\hline & LTPO6 & 0.620 & & \\
\hline \multirow[t]{4}{*}{ Meritensnce Poicy } & pousi & 0.913 & 0.945 & 0810 \\
\hline & pous2 & 0.625 & & \\
\hline & Pous3 & 0.680 & & \\
\hline & Pous4 & 0.603 & & \\
\hline \multirow[t]{7}{*}{ Martenance Cuhure } & KPEP1 & 0.807 & 0.940 & 0.691 \\
\hline & КPQP2 & 0.784 & & \\
\hline & КРEP3 & 0.798 & & \\
\hline & КРEP4 & 0.844 & & \\
\hline & KPEPS & 0.870 & & \\
\hline & КРЕP6 & 0.835 & & \\
\hline & KPEPT & 0.846 & & \\
\hline
\end{tabular}

Besides that, the discriminant validity were tested to examine that the square root of the AVE of a particular construct was greater than the variance shared between that construct and other constructs in the model (Hulland, 1999). Based on results presented in Table 4, indicate that the model exhibited satisfactory validity criteria.

Table 4: Discriminant Validity

\begin{tabular}{llllllll}
\hline Constructs & 1 & 2 & 3 & 4 & 5 & 6 & 7 \\
\hline 1. Communication & 0.864 & & & & & & \\
2.Teamwork & 0.680 & 0.839 & & & & & \\
3. Maintenance Culture & 0.523 & 0.507 & 0.831 & & & & \\
4. Leadership. & 0.546 & 0.672 & 0.439 & 0.833 & & & \\
5 Involvement & 0.790 & 0.743 & 0.540 & 0.618 & 0.840 & & \\
6. Training and Education & 0.689 & 0.694 & 0.413 & 0.494 & 0.700 & 0.862 & \\
7. Maintenance Policy & 0.727 & 0.703 & 0.526 & 0.615 & 0.782 & 0.793 & 0.900 \\
\hline
\end{tabular}

\subsection{Structural model}

Next, the structural model produced in intended to investigate the latent variables relationship between key determinant factors of maintenance culture with maintenance culture namely, KPASU, KOMUN, KPIMN, KPBP, LIBAT, LTPD and POLIS. Figure 3 and Table 5 illustrate the results from analysis applicable to the $R^{2}$ values for the coefficient of determination of the endogenous latent variables and the path coefficients $(b)$ for the model.

The bootstrapping 500 resamples as adopted to calculate standard errors and t-statistics. The results reveal that $R^{2}$ for this model was 0.353 , this implies that $35.3 \%$ of the variance in 
maintenance culture were contributed by the six key determinant factors of maintenance culture.

The postulated model (Figure 3) verified the path coefficients for five key determinant factors of maintenance culture has significant and direct effect relationship with maintenance culture. The relationship between all constructs (KPASU, KOMUN, LIBAT and POLIS) was to be significantly with maintenance culture having the standardised path coefficients of range 0.15 to 0.24 also the level t-statistics were over 1.645 .

However, the relationship between LTPD and KPBP was found to be significantly negative having the path coefficient of -0.163 . Meanwhile, leadership factors (KPIMN) was not significantly of relationship with maintenance culture. Thus, the hypotheses for $\mathrm{H} 2, \mathrm{H} 3$, $\mathrm{H} 4$, and $\mathrm{H} 5, \mathrm{H} 6$ are supported while $\mathrm{H} 1$ is not supported.

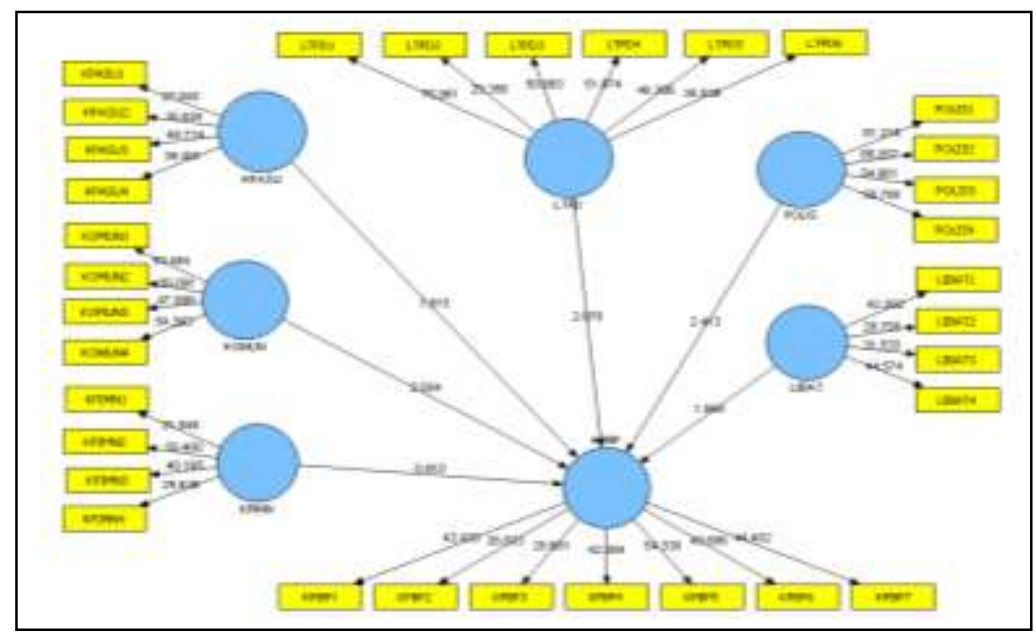

Fig. 3: Structural Model

Table 5. Measurement Model Results

\begin{tabular}{|c|c|c|c|c|c|}
\hline Hypotheses & Path & Description & $\begin{array}{l}\text { Path Coefficient } \\
\text { ( } \beta)\end{array}$ & t-value & Results \\
\hline$H 1$ & $\mathrm{KPIMN} \rightarrow \mathrm{KPBP}$ & Leadership $\rightarrow$ Maintenance Culture & 0.060 & 0.910 & $\begin{array}{l}\text { Not } \\
\text { supported }\end{array}$ \\
\hline H2 & $\mathrm{KPASU} \rightarrow \mathrm{KPBP}$ & Teamwork $\rightarrow$ Maintenance Culture & 0.163 & $1.815^{*}$ & Supported \\
\hline$H 3$ & $\mathrm{KOMUN} \rightarrow \mathrm{KPBP}$ & Communication $\rightarrow$ Maintenance Culture & 0.196 & $2.504^{\star *}$ & Supported \\
\hline H4 & LIBAT $\rightarrow$ KPBP & Involvement $\rightarrow$ Maintenance Culture & 0.150 & $1.959^{* *}$ & Supported \\
\hline H5 & LTPD $\rightarrow K P B P$ & $\begin{array}{l}\text { Training and Education } \rightarrow \text { Maintenance } \\
\text { Culture }\end{array}$ & -0.163 & $2.078^{* \star}$ & Supported \\
\hline$H 6$ & POLIS $\rightarrow$ KPBP & Maintenance Policy $\rightarrow$ Maintenance Culture & 0.243 & $2.413^{* \star}$ & Supported \\
\hline
\end{tabular}




\subsection{Discussion on findings of six hypotheses}

The discussions of the findings were more focused to test six hypotheses that had developed in this research.

Hypotheses 1 proposed that there is a relationship between leadership (KPIMN) and maintenance culture. However, leadership factor $(\beta=0.060)$ has a non-significant effect on maintenance culture. Hence, this hypothesis is rejected. Khoiri (2010) in safety culture also found the same results that leadership was not significant in affecting safety culture development. Leadership is a crucial part of the process of creating effective management and determining the direction of the organisation to ensure that planned objectives achieved successfully.

Hypotheses 2 suggested that there is a relationship between teamwork (KPASU) and maintenance culture. The $\beta$ values of teamwork factors are $0.163(p<0.10)$. Hence, the hypothesis is accepted. Results indicate that there is the significant relationship between teamwork and maintenance culture. This is also consistent with the previous studies in the quality area by Rita (2003), MohammadZadeh and Saghaei (2009), Demirbag and Sahadev (2008) that empirically proven that there is a positive relationship between teamwork and maintenance culture. Teamwork is a combination of effort, knowledge, skills and the ability of a group of individuals to achieve maintenance work performance to the higher level than an individual. Teamwork exists around the hierarchy of that organisation involving the cooperation in problem-solving regarding due to management and maintenance work arising will able created a maintenance culture in an organisation.

Hypotheses 3 proposed that communication (KOMUN) factors significantly influence developing maintenance culture. Results conclude that this hypothesis has a $\beta$ value 0.196 $(p<0.05)$. Thus, $\mathrm{H} 3$ was supported by statistical analysis where it indicates that there is the significant relationship between communication factors and maintenance culture. This result is supported by theory and empirical findings from several researchers in quality and safety culture area (Rita, 2003; Andi et al., 2005; MohammadZadeh and Saghaei, 2009; Khoiri, 2010; Christinaet al., 2012; Demirbag and Sahadev, 2008). The existences of effective communication between management and staffs are a crucial factor for improving competence and encourage staff involvement in each maintenance task. The communication should be occurred efficiently to ensure that transferable information or instructions can be delivered quickly, accurately and easily understandable.

Hypotheses 4 posits that involvement (LIBAT) significantly influences maintenance culture. The $\beta$ values of involvement factors are 0.150 ( $p<0.05)$. Thus, the hypothesis is accepted and in line with the previous empirical research in safety and quality culture by Rita, 2003; Viljoen dan Waveren, 2008; Mohd Saidin, 2009). Involvement factors are crucial where the management parties were giving all maintenance staff authority to make the decision and find the solution toward maintenance work, from that every person will understand the roles and responsibilities of themselves and take as a part of the whole planning in the organisation.

Hypotheses 5 estimates that training and education (LTPD) factors have a positive relationship with maintenance culture. Beta value for this factor of -0.163 , this finding is not aligned with hypotheses developed. However, this factor is significant with the maintenance 
culture because the value of t-statistic is above -1.645 , thus the hypotheses are accepted. This results also had reported in previous research by Rita (2003); MohammadZadeh and Saghaei (2009); Khoiri (2010); Christina et al. (2012). This result is not aligned caused respondents feel that the implementation of training and education received on the scope of maintenance work often does not appropriate based on their job specification.

The maintenance policies (POLIS) factor results supported for hypotheses $6(\mathrm{H} 6)$ that POLIS has a significant and direct effect on maintenance culture. The $\beta$ values of involvement factors are $0.243(p<0.05)$. This finding is consistent with results from previous research where policies are one of the significant factors to develop culture (Andi et al., 2005; Viljoen dan Waveren, 2008; Mohd Saidin, 2009; Khoiri, 2010). Policies and work procedures as strategies to augment staffs knowledge and level of competence toward maintenance work. Role of policies is essential as guidance and instructions to employees in respect of their job description.

Therefore, from this results indicate that developing of maintenance culture were influenced by five determinant factors. Communication factors are the key success factors that contribute to develop of maintenance culture followed by maintenance policy, training and education, involvement, and teamwork. However, this study has shown that leadership is not important factors for developing maintenance culture. This result was not unexpected because based on previous research have found that leadership is an important factor in the development of maintenance culture.

\subsection{Conclusion}

This study produced and estimated a structural model in developing Maintenance Culture in Malaysian Local Authorities with the objective of this research is to explore the relationships between the six key determinant factors of maintenance culture with maintenance culture. For the conclusion, the use of structural equation model (SEM) techniques have been effectively established a model of maintenance culture. This study provides significant value and contribution to knowledge and theory development of a model that incorporates various variables or constructs found from the review of previous research which has not been analysed or tested statistically. This study brings implications to Malaysian Local Authorities because it assists in solving the maintenance problems that occur where the changes required on the people attitude and perception toward managing of public facilities. Maintenance culture should be as a way of life and always practised by the whole society to ensure that existing infrastructures will sustain to future generations. This research has found five factors should be taken into account to success maintenance culture, which is communication, maintenance policies, involvement, teamwork and, training and education factors. Therefore, to enhance the maintenance culture development in local authorities, this research suggested that for the future research will focus specific study on leadership factors. 


\section{Acknowledgement}

The researcher would like to state recognition towards respondents from local authorities for all their cooperation in this research. Finally, the researcher would also like to express appreciation to Universiti Teknologi MARA, Perak Branch for continued support.

\section{References}

Andi, A., Alifen, R. S., \& Chandra, A. (2005). Model persamaan struktural pengaruh budaya keselamatan kerja pada perilaku pekerja di proyek konstruksi. Jurnal Teknik Sipil, 12(3), 127-136.

Bernstein, I. H., \& Nunnally, J. C. (1994). Psychometric theory. New York: McGraw-Hill.

Christina, W. Y., Djakfar, L., \& Thoyib, A. (2012). Pengaruh Budaya Keselamatan dan Kesehatan Kerja (K3) terhadap kinerja proyek konstruksi. Rekayasa Sipil, 6(1), 83-95.

Demirbag, M., \& Sahadev, S. (2008). Exploring the antecedents of quality commitment among employees: an empirical study. International Journal of Quality \& Reliability Management, 25(5), 494-507.

Florence. (2011). An empirical analysis of asset replacement decisions and maintenance culture in some government organizations located in ogbomoso and ilorin metropolis as case Study. Journal of Management and Society, 1(3), 01-09.

Fornell, C., \& Larcker, D. F. (1981). Evaluating structural equation models with unobservable variables and measurement error. Journal of Marketing Research, 39-50.

Hair, J. F., Black, W. C., Babin, B. J., Anderson, R. E., \& Tatham, R. L. (2010). Multivariate data analysis (Vol.7). Upper Saddle River, NJ: Prentice hall.

Henseler, J., Ringle, C. M., \& Sinkovics, R. R. (2009). The use of partial least squares path modeling in international marketing. In New challenges to international marketing (pp. 277-319). Emerald Group Publishing Limited.

Hulland, J. (1999). Use of partial least squares (PLS) in strategic management research: A review of four recent studies. Strategic Management Journal, 195-204.

Kamaruddin, R., Osman, I., \& Pei, C. A. C. (2017). Customer expectations and its relationship towards public transport in Klang Valley. Journal of ASIAN Behavioural Studies, 2(4), 29-39.

Khoiri, M. (2010). Upaya peningkatan budaya keselamatan pekerja radiasi rumah sakit di Indonesia. In Seminar Nasional VI SDM Teknologi Nuklir.

Misnan, M. S., \& Samlawi, S. (2012). Usaha Menerapkan Budaya Penyelenggaraan Dalam Sektor Perkhidmatan Awam Di Malaysia. The Professional Jurnal of Royal Institution of Surveyors Malaysia, 47(1), 16-25.

MohammadZadeh, S., \& Saghaei, A. (2009, July). Using structural equation modeling for measuring quality culture in a construction company. In Computers \& Industrial Engineering, 2009. CIE 2009. International Conference on (pp. 1320-1324). IEEE.

Mohd Suki, N., Ramayah, T., \& Mohd Suki, N. (2011). Understanding consumer intention with respect to purchase and use of pirated software. Information Management \& Computer Security, 19(3), 195-210.

Mohd. Saidin Misnan. (2009). Model membangunkan budaya keselamatan dalam firma pembinaan di 
Malaysia (Doctoral dissertation, Universiti Teknologi Malaysia).

Odediran, S. J., Opatunji, O. A., \& Eghenure, F. O. (2012). Maintenance of residential buildings: users' practices in Nigeria. Journal of Emerging Trends in Economics and Management Sciences, 3(3), 261.

Olufunke, A. M. (2011). Education for maintenance culture in Nigeria: Implications for community development. International Journal of Sociology and Anthropology, 3(8), 290.

Perumal, V. R., \& Bakar, A. H. A. (2011). The needs for standardization of document towards an efficient communication in the construction industry. Acta technica corviniensis-Bulletin of engineering, 4(1), 23.

Reiman, T., \& Oedewald, P. (2004). Measuring maintenance culture and maintenance core task with CULTUREquestionnaire-a case study in the power industry. Safety Science, 42(9), 859-889.

Rita, E. (2003). Pembangunan budaya kualiti dalam firma pembinaan di Indonesia. Universiti Teknologi Malaysia: PhD Thesis.

Saad, M., Abdullah, M. F. F., Jeinie, M. H., \& Husain, R. (2017). Facilitating best food-hygiene practices through effective leadership. Asian Journal of Behavioural Studies, 2(6), 21-32.

Sani, S. I. A., Mohammed, A. H., \& Misnan, M. S. (2014). Analysis of the determinant factors development of maintenance culture in Malaysian Local Authorities. In MATEC Web of Conferences (Vol. 15, p. 01005). EDP Sciences.

Sani, S. I. A., Mohammed, A. H., Misnan, M. S., \& Awang, M. (2012). Determinant factors in development of maintenance culture in managing public asset and facilities. Procedia-Social and Behavioral Sciences, 65, 827-832.

Suwaibatul Islamiah, A. S., Abdul Hakim, M., Syazwina, F. A. S., \& Eizzatul, A. S. (2012). An overview development of maintenance culture. In 3rd International Conference on Business and Economic Research. Proceeding Conference (pp. 2206-2217).

Syed-Abdullah, S. L., Omar, M., \& Idris, M. F. I. M. (2011). Team achievements equality using fuzzy rule-based technique. World Appl. Sci. J, 15(3), 359-363.

Tungkunanan, P., Leekitchwatana, P., Pimsarn, N., \& Chumnum, S. (2008). Strategic plan for developing quality culture at Eastern School of the Office of Vocational Education Commission, Thailand. ABAC Journal, 28(2).

Urbach, N., \& Ahlemann, F. (2010). Structural equation modeling in information systems research using partial least squares. JITTA: Journal of Information Technology Theory and Application, 11(2), 5.

Viljoen, S. J., \& van Waveren, C. C. (2008, July). An improved model for quantifying an organisational quality culture. In Management of Engineering \& Technology, 2008. PICMET 2008. Portland International Conference on (pp. 17811789). IEEE.

Zabihi, M., Hashemzehi, R., \& Tabrizi, K. G. (2012). Impacts of transactional and transformational leaderships upon organizational citizenship behavior. World Applied Sciences Journal, 16(8), 1176-1182.

Zou, P. X. (2010). Fostering a strong construction safety culture. Leadership and Management in Engineering, 11(1), 11-22. 